\title{
Effect of particle size of soft wheat flour on the development of Ephestia kuehniella Zeller (Lepidoptera: Pyralidae)
}

\author{
Daria P. Locatelli, Lidia Limonta*, Massimiliano Stampini \\ Istituto di Entomologia agraria, Università degli Studidi Milano, Via Celoria 2, 20133 Milano, Italy
}

\section{A R T I C L E I N F O}

Article history:

Accepted 10 February 2008

\section{Keywords:}

Ephestia kuehniella Zeller

Flour moth

Refined flour

Particle size

Attractiveness

\begin{abstract}
A B S T R A C T
The effect of soft wheat flours, characterized by different particle size, protein and starch content, on the development of Ephestia kuehniella was studied. The attractiveness of the substrata to first and third instar larvae was also considered.

The different protein content of the flours did not significantly affect the development of E. kuehniella, nor did it affect the ability of the flours to attract larvae. In tests with soft wheat flours with the same nutritional value but different particle size, the highest mean number of adults and the shortest developmental period were recorded on samples with greatest particle size $(250-419 \mu \mathrm{m})$.

In order to test the attractiveness of soft wheat flour to larvae, a one-way olfactometer was used. There were no significant differences observed in the number of first and third instar larvae found on flours with different protein composition and particle size. Larvae of this species show limited mobility, in fact few individuals of either instar can reach the flour from a distance of $2 \mathrm{~m}$. No larvae of either instar contacted the different substrata from a distance of $2.5 \mathrm{~m}$.
\end{abstract}

(c) 2008 Elsevier Ltd. All rights reserved.

\section{Introduction}

Ephestia kuehniella Zeller is a cosmopolitan pest of cereals, their by-products, and of nuts and legumes (Candura, 1928). In the temperate zone it is a widespread pest of mills where it can develop both on grain and flour.

First instar larvae of E. kuehniella eat only the embryo of whole kernels, as it is particularly tender and rich in proteins, while larvae of the later instars also attack the pericarp (Fraenkel and Blewett, 1943a; Rathore et al., 1980). The development of larvae is faster on ground kernels (Kunike, 1938). This has also been observed for Plodia interpunctella (Hübner), Cadra cautella (Walker) (Lecato, 1976), and Corcyra cephalonica (Stainton) (Sharma et al., 1978; Osman, 1986; Mbata, 1989).

Ephestia kuehniella has fewer nutritional needs compared with other pyralids, as it can also develop on refined flours (Jacob and Cox, 1977; Stein and Parra, 1987). This species needs a diet rich in carbohydrates (Fraenkel and Blewett, 1943b), and it was observed that a diet with flours deprived of protein fractions (gliadins, albumins, and globulins) retards the development of the insect and increases mortality in pupae (Nawrot et al., 1985).

Wheat flours present different particle sizes according to the physical characteristics of the grain (hardness, vitreosity) and

\footnotetext{
* Corresponding author. Tel.: +3902 50316753; fax: +390250316748

E-mail address: lidia.limonta@unimi.it (L. Limonta).
}

milling extraction rate; therefore, the effect of particle size on the development of the moth and on the attractiveness of flours to larvae was studied.

\section{Materials and methods}

Laboratory cultures of the moth E. kuehniella maintained in a rearing room at $26 \pm 1{ }^{\circ} \mathrm{C}$ and $70 \pm 5 \%$ relative humidity (r.h.), were used for these experiments.

In test 1, two groups of soft wheat flours, A and B, marketed in Italy, were tested. Three different percentage distributions of the particle sizes were considered for each group of flour (A1, A2, A3, B1, B2, B3) (Table 1).

In test 2, a flour, deriving from a single grinding process, corresponding to the extraction of the inner endosperm, composed only of starchy endosperm, and therefore characterized by relatively homogeneous composition, was sieved into nine particle size classes.

The tests were carried out by placing $50 \mathrm{~g}$ of flour in each of several polystyrene containers (diameter $120 \mathrm{~mm}$, height $65 \mathrm{~mm}$ ). A small plate containing 100 eggs of $E$. kuehniella was placed in the middle of each container. The containers, closed with gauze (120 mesh) to provide ventilation were placed in an incubator at $26 \pm 1{ }^{\circ} \mathrm{C}, 70 \pm 5 \%$ r.h. and $16 \mathrm{~h}$ of light alternating with $8 \mathrm{~h}$ of darkness. After 5 days, the unhatched eggs were counted with a binocular microscope. After a 20-day period, first generation 
Table 1

Composition of soft wheat flour and percentage distribution by particle size

\begin{tabular}{|c|c|c|c|c|c|c|c|c|c|c|}
\hline \multirow[t]{2}{*}{ Flours $^{\mathrm{a}}$} & \multicolumn{4}{|l|}{ Composition } & \multicolumn{6}{|c|}{ \% Distribution by particle size $(\mu \mathrm{m})$} \\
\hline & Carbohydrates & Proteins & Other & Moisture & $>159$ & $158-142$ & $141-124$ & $123-116$ & $115-106$ & $<105$ \\
\hline A1 & 72.8 & 12.3 & 2.6 & 12.3 & 98.8 & 0.6 & 0.3 & 0.2 & 0.1 & 0 \\
\hline A2 & 73.1 & 12.1 & 2.3 & 12.5 & 9 & 75 & 12 & 2 & 1 & 1 \\
\hline A3 & 73.2 & 11.7 & 2.5 & 12.6 & 2 & 23 & 32 & 17 & 14 & 12 \\
\hline B1 & 70.1 & 14.3 & 2.4 & 13.2 & 98.3 & 1.3 & 0.2 & 0.1 & 0.1 & 0 \\
\hline B2 & 70.4 & 14.1 & 2.3 & 13.2 & 6 & 71 & 16 & 3 & 2 & 2 \\
\hline B3 & 70.6 & 14.2 & 2.5 & 12.7 & 1 & 8 & 17 & 29 & 21 & 24 \\
\hline
\end{tabular}

B: soft wheat: $80 \%$ Manitoba (Canada), 10\% North Spring (USA), 10\% Kazaco (Kazachistan).

Particle size: 1: greater; 2: intermediate; 3: smaller.

${ }^{a}$ A: soft wheat Misto Rosso (100\%) (Italy).

adults were counted and removed daily for the month following the first adult emergence.

Adult emergence data were corrected for variations in percentage hatch of eggs in order to compare results of the six replicates on the different flours. The data were based on 100-hatched eggs. The developmental period was counted from the time the eggs were laid to the time when $50 \%$ of the total adults emerged. Based on the percentage of adult emergence and on the period of development, the susceptibility index (Dobie, 1974) was determined according to the method of Howe (1971). The index is calculated as $\left(\log _{\mathrm{e}} y\right) / t$; where $y$ is the number of progeny produced and $t$ the duration of development.

Data from tests 1 and 2 were analyzed using Duncan's multiple range test (SPSS 10.0 per Windows).

In test 3 , the attractiveness of soft wheat flours to larvae was evaluated using polypropylene one-way olfactometers placed in a room at $26 \pm 1{ }^{\circ} \mathrm{C}, 70 \pm 5 \%$ r.h. and $16 \mathrm{~h}$ of light alternating with $8 \mathrm{~h}$ of darkness. Each olfactometer (thickness $30 \mu \mathrm{m}$; diameter $19 \mathrm{~cm}$; length variable from 1 to $2.5 \mathrm{~m}$ ) had $30 \%$ of its surface as a netcovered opening to allow gas exchange and the two ends of the olfactometer were covered with a net to insert insects and food substrates (Locatelli and Limonta, 2004). Flours A1, A3, B1, and B3, were tested. Newly hatched larvae were obtained from 100 eggs 24 to $48 \mathrm{~h}$ old. At the test conditions, eggs hatch in 5-6 days. Eggs were placed on a small disk (diameter $4 \mathrm{~cm}$ ) of black paper at one end of the olfactometer, while at the other end $50 \mathrm{~g}$ of soft wheat flour were placed on another small disk of black paper. After 10 days, the soft wheat flour was placed in polystyrene containers under the same conditions as the test; first instar larvae that reached the soft wheat flour were counted after 7 days. Tests with third instar larvae were carried out with the same method; for each test groups of 20 larvae, previously starved for $48 \mathrm{~h}$, were used. Third instar larvae that reached the soft wheat flour were counted after 4 days.

Four replicates were carried out for each soft wheat flour and control (without food). In the control the soft wheat flour was substituted by glued paper, in order to catch larvae. Data were expressed as the percentage of larvae reaching the food (or paper) and, before statistical analysis, an arcsine transformation was applied.

Data were submitted to ANOVA and Dunnett's test (SPSS 10.0 for Windows).

\section{Results}

\subsection{Test 1: effect of protein content and of particle size}

In Tables 2 and 3, the results of the effect of protein content and of particle size of the soft wheat flours on the development of
Table 2

Mean number $( \pm$ SE) of Ephestia kuehniella adults originating from 100 eggs, mean developmental period $( \pm \mathrm{SE})$ and susceptibility index observed on softwheat flour $A^{\mathrm{a}}$ with different particle size

\begin{tabular}{llll}
\hline Flour & $\begin{array}{l}\text { Mean number of } \\
\text { adults }\end{array}$ & $\begin{array}{l}\text { Mean developmental } \\
\text { period }\end{array}$ & $\begin{array}{l}\text { Susceptibility } \\
\text { index }\end{array}$ \\
\hline A1 & $78.5 \pm 0.9 \mathrm{a}$ & $42.2 \pm 0.4 \mathrm{c}$ & $4.50 \pm 0.05 \mathrm{a}$ \\
$\mathrm{A} 2$ & $68.0 \pm 1.9 \mathrm{~b}$ & $49.8 \pm 0.5 \mathrm{~b}$ & $3.70 \pm 0.05 \mathrm{~b}$ \\
$\mathrm{~A} 3$ & $66.2 \pm 1.7 \mathrm{~b}$ & $59.7 \pm 0.3 \mathrm{a}$ & $3.05 \pm 0.03 \mathrm{c}$ \\
\hline
\end{tabular}

Means followed by different letter in a column are significantly different $(P<0.05$ Duncan's multiple range test).

a Soft wheat Misto Rosso (100\%) (Italy).

b Particle size: 1: greater; 2: intermediate; 3: smaller.

Table 3

Mean number $( \pm$ S.E.) of Ephestia kuehniella adults, mean developmental period $\left( \pm\right.$ S.E.) observed on softwheat flour $B^{\mathrm{a}}$ with different particle size

\begin{tabular}{llll}
\hline Flour & $\begin{array}{l}\text { Mean number of } \\
\text { adults }\end{array}$ & $\begin{array}{l}\text { Mean developmental } \\
\text { period }\end{array}$ & $\begin{array}{l}\text { Susceptibility } \\
\text { index }\end{array}$ \\
\hline B1 $^{\mathrm{b}}$ & $78.7 \pm 0.9 \mathrm{a}$ & $41.8 \pm 0.2 \mathrm{c}$ & $4.52 \pm 0.02 \mathrm{a}$ \\
$\mathrm{B} 2$ & $64.7 \pm 0.8 \mathrm{~b}$ & $51.0 \pm 0.5 \mathrm{~b}$ & $3.57 \pm 0.04 \mathrm{~b}$ \\
B3 & $62.0 \pm 2.0 \mathrm{~b}$ & $60.5 \pm 0.8 \mathrm{a}$ & $2.93 \pm 0.06 \mathrm{c}$ \\
\hline
\end{tabular}

Means followed by different letter in a column are significantly different $(P<0.05$ Duncan's multiple range test).

a Soft wheat: $80 \%$ Manitoba (Canada), 10\% North Spring (USA), 10\% Kazaco (Kazachistan).

${ }^{\mathrm{b}}$ Particle size: 1: greater; 2: intermediate; 3: smaller.

E. kuehniella are reported. A higher mean number of adults $(78.5 \pm 0.9 ; 78.7 \pm 0.9)$ and a shorter developmental period $(42.2 \pm 0.4 ; 41.8 \pm 0.2)$ were recorded with the two soft wheat flours with greater particle size (A1 and B1). Soft wheat flours of intermediate $(A 2, B 2)$ and smaller $(A 3, B 3)$ particle size produced a similar mean number of adults, but the mean developmental period $(59.7 \pm 0.3 ; 60.5 \pm 0.8)$ was longer and the susceptibility indices (Tables 2 and 3 ) were lower $(3.05 \pm 0.03 ; 2.93 \pm 0.06)$ on soft wheat flours with smaller particle size. Soft wheat flour B, characterized by a higher protein content, yielded a susceptibility index (Table 3) similar to that for soft wheat flour A.

\subsection{Test 2: effect of particle size}

In tests with soft wheat flours of the same composition but different particle sizes (Table 4), higher mean numbers of adults were recorded on soft wheat flours 1,2 and $3(78.7 \pm 1 ; 79 \pm 1$; $78.2 \pm 1)$ with greater particle size $(250-419 \mu \mathrm{m})$, while the lowest mean number of adults $(25.7 \pm 1.3)$, the longest developmental 
Table 4

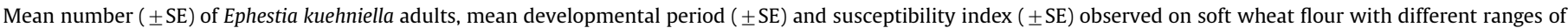
particle size

\begin{tabular}{|c|c|c|c|c|}
\hline Soft wheat flour ${ }^{a}$ & Particle size $(\mu \mathrm{m})$ & Mean number of adults & Mean developmental period & Susceptibility index \\
\hline 1 & $419-350$ & $78.7 \pm 1.0 \mathrm{a}$ & $39.0 \pm 0.3 \mathrm{~h}$ & $4.85 \pm 0.04 a$ \\
\hline 2 & $349-290$ & $79.0 \pm 1.0 a$ & $39.7 \pm 0.2 \mathrm{gh}$ & $4.78 \pm 0.04 a$ \\
\hline 3 & $289-250$ & $78.2 \pm 1.0 \mathrm{a}$ & $41.5 \pm 0.2 \mathrm{~g}$ & $4.58 \pm 0.03 b$ \\
\hline 4 & 249-159 & $60.7 \pm 0.7 b$ & $59.0 \pm 0.3 f$ & $3.02 \pm 0.02 c$ \\
\hline 5 & $158-142$ & $53.3 \pm 1.7 c$ & $68.3 \pm 0.5 e$ & $2.52 \pm 0.04 d$ \\
\hline 6 & $141-124$ & $42.7 \pm 1.2 \mathrm{~d}$ & $75.2 \pm 0.8 \mathrm{~d}$ & $2.17 \pm 0.03 e$ \\
\hline 7 & $123-116$ & $34.3 \pm 1.3 \mathrm{e}$ & $78.2 \pm 1.3 c$ & $1.95 \pm 0.04 f$ \\
\hline 8 & $115-106$ & $31.5 \pm 1.1 \mathrm{e}$ & $86.0 \pm 1.1 b$ & $1.73 \pm 0.02 \mathrm{~g}$ \\
\hline 9 & $105-63$ & $25.7 \pm 1.3 f$ & $94.8 \pm 1.4 a$ & $1.50 \pm 0.03 h$ \\
\hline
\end{tabular}

Means followed by different letter in a column are significantly different $(P<0.05$, Duncan's multiple range test).

${ }^{a}$ Composition: carbohydrates: 72.3; proteins: 12.3; other: 2.5; moisture: 12.9. Soft wheat Misto Rosso (100\%) (Italy).

Table 5

Mean number $( \pm$ S.E.) of first instar larvae, derived from 100 eggs, present in soft wheat flour A1 and A3 placed at varying distance

\begin{tabular}{lccc}
\hline Soft wheat flour & \multicolumn{2}{l}{ Distance $(\mathrm{m})$} & \\
\cline { 2 - 4 } & 1 & 2 & 2.5 \\
\hline A1 $^{\mathrm{b}}$ & $13.3 \pm 0.6$ & $1.5 \pm 0.5$ & 0 \\
$\mathrm{~A} 3$ & $14.5 \pm 0.6$ & $1.3 \pm 0.5$ & 0 \\
Control & $1.3 \pm 0.8$ & $0.0 \pm 0.0$ & 0 \\
Dunnett's test & Mean difference & & \\
A1-Control & $0.29^{\mathrm{a}}$ & $0.19^{\mathrm{a}}$ & \\
A3-Control & $0.31^{\mathrm{a}}$ & $0.09^{\mathrm{a}}$ & \\
\hline
\end{tabular}

Particle size 1: greater; 3:smaller.

a The mean difference is significant at the 0.05 level (Dunnett's test).

${ }^{\mathrm{b}}$ A: soft wheat Misto Rosso (100\%) (Italy).

period $(94.8 \pm 1.4)$ and the lowest susceptibility index $(1.5 \pm 0.03)$ were recorded on soft wheat flour 9 , characterized by the smallest particle size $(63-105 \mu \mathrm{m})$. The mean developmental period increased when the particle size of flour decreased. The highest susceptibility indices were observed on soft wheat flour classes 1 $(4.85 \pm 0.04)$ and $2(4.78 \pm 0.04)$ characterized by greater particle size and susceptibility indices decreased with diminishing particle size.

\subsection{Test 3: attractiveness of flours}

In tests with a one-way olfactometer (Tables 5-8), no significant differences were observed among the mean numbers or mean percentages of first and third instar larvae attracted by soft wheat flours with different protein composition and different particle size. The mean number of first instar larvae that reached soft wheat flours A and B from a distance of $1 \mathrm{~m}$ varied from 13.3 to 14.5 out of 100 , while it varied from 1.3 to 1.8 from a distance of $2 \mathrm{~m}$ (Tables 5 and 6). A significant difference between different types of flour and the control was observed at a distance of 1 and $2 \mathrm{~m}$ for first instar larvae.

A higher mean percentage (36.2\%) of third instar larvae, compared to first instar larvae (25.0\%), reached soft wheat flours from a distance of $1 \mathrm{~m}$ (Tables 7 and 8). In the case of third instar larvae a significant difference was observed between the different types of flour and the control at $1 \mathrm{~m}$ distance. A high variability among the individuals was observed in the test at $2 \mathrm{~m}$ distance (S.E. 2.5-2.9).

No larvae of either instar could reach the soft wheat flours from a distance of $2.5 \mathrm{~m}$.
Table 6

Mean number ( \pm S.E.) of first instar larvae, derived from 100 eggs, present in soft wheat flour B1 and B3 placed at varying distance

\begin{tabular}{lccc}
\hline Soft wheat flour & \multicolumn{2}{l}{ Distance $(\mathrm{m})$} & 2.5 \\
\cline { 2 - 4 } & 1 & 2 & 0 \\
& $13.8 \pm 0.9$ & $1.3 \pm 0.5$ & 0 \\
B1 $^{\mathrm{b}}$ & $14.3 \pm 0.5$ & $1.8 \pm 0.3$ & 0 \\
B3 & $1.3 \pm 0.8$ & $0.0 \pm 0.0$ & \\
Control & Mean difference & & \\
Dunnett's test & $0.3^{\mathrm{a}}$ & $0.09^{\mathrm{a}}$ & \\
B1-Control & $0.3^{\mathrm{a}}$ & $0.13^{\mathrm{a}}$ & \\
B3-Control & 3. & & \\
\hline
\end{tabular}

Particle size 1: greater; 3 :smaller.

${ }^{a}$ The mean difference is significant at the 0.05 level (Dunnett's test).

b B: soft wheat blend: 80\% Manitoba (Canada), 10\% North Spring (USA), 10\% Kazaco (Kazachistan).

Table 7

Mean percentage ( \pm S.E.) of third instar larvae present in soft wheat flours A1 and A3 placed at varying distance

\begin{tabular}{lccc}
\hline Soft wheat flour & \multicolumn{2}{l}{ Distance $(\mathrm{m})$} & \\
\cline { 2 - 4 } & 1 & 2 & 2.5 \\
\hline A1 $^{\mathrm{b}}$ & $25.0 \pm 7.1$ & $1.25 \pm 2.5$ & 0 \\
A3 & $28.7 \pm 6.3$ & $2.5 \pm 2.9$ & 0 \\
Control & $5 \pm 4.1$ & $0.0 \pm 0.0$ & 0 \\
Dunnett's test & Mean difference & & \\
A1-Control & $0.32^{\mathrm{a}}$ & $0.05 \mathrm{~ns}$ & \\
A3-Control & $0.37^{\mathrm{a}}$ & $0.11 \mathrm{~ns}$ & \\
\hline
\end{tabular}

Particle size 1: greater; 3:smaller.

ns: The mean difference is not significant (Dunnett's test).

a The mean difference is significant at the 0.05 level.

${ }^{\mathrm{b}}$ A: soft wheat Misto Rosso (100\%) (Italy).

\section{Discussion}

The different protein content of the two groups of soft wheat flours did not significantly influence the development of E. kuehniella nor the ability of the two groups of substrata to attract first and third instar larvae.

This pest, when reared on durum wheat flour, characterized by a higher protein content compared to soft wheat flour, produced more progeny with a shorter mean developmental period. Trematerra et al. (1984) observed mean developmental times at $25^{\circ} \mathrm{C}$ from 42.8 to 59.8 days in soft wheat flours and from 40.3 to 42.1 days in durum wheat flours; the variation in each group was 
Table 8

Mean percentage $( \pm$ S.E.) of third instar larvae present in soft wheat flours B1 and B3 placed at varying distance

\begin{tabular}{llcc}
\hline Soft wheat flour & \multicolumn{2}{l}{ Distance $(\mathrm{m})$} & 2.5 \\
\cline { 2 - 4 } & 1 & 2 & 0 \\
& & $2.5 \pm 2.9$ & 0 \\
B1 $^{\mathrm{b}}$ & $30.0 \pm 9.1$ & $1.25 \pm 2.5$ & 0 \\
B3 & $36.2 \pm 7.5$ & $0.0 \pm 0.0$ & \\
Control & $5 \pm 4.1$ & & \\
Dunnett's test & Mean difference & $0.11 \mathrm{~ns}$ & \\
B1-Control & $0.38^{\mathrm{a}}$ & $0.05 \mathrm{~ns}$ & \\
B3-Control & $0.45^{\mathrm{a}}$ & & \\
\hline
\end{tabular}

Particle size 1: greater; 3:smaller.

ns: The mean difference is not significant (Dunnett's test)

a The mean difference is significant at the 0.05 level.

b B: soft wheat blend: $80 \%$ Manitoba (Canada), 10\% North Spring (USA), 10\% Kazaco (Kazachistan)

associated with the cultivars. Durum wheat flours favor the development of E. kuehniella as they provide a higher quantity of water-soluble and liposoluble vitamins, essential for the synthesis of essential coenzymes (Fraenkel and Blewett, 1943c, 1946; Morère, 1971). In these papers, the particle size of flours was not considered. The results of this research show that the particle size of soft wheat flours influences both the percentage of adults emerging and the mean developmental time of E. kuehniella. This is confirmed by the results of tests with soft wheat flours characterized by the same nutritional composition but different particle size. The mean number of adults decreases and the developmental period increases when the particle size of soft wheat flours is smaller; the highest mean number of adults and the shortest developmental period were observed with soft wheat flours with a particle size greater than $249 \mu \mathrm{m}$. In a volume, decreasing particle size reduces interstitial space, and therefore, the diffusion of gases decreases. It was observed that in cereals, treated with modified atmospheres, a large amount of dust negatively influences the diffusion of gases (MAFF, 1983; Süss et al., 1988). Flours characterized by a smaller particle size could show low rates of diffusion of air (due to restricted interstitial space), and therefore, reduce the amount of available oxygen, slowing insect development. Besides, larger particles improve the ability of larvae to tie pieces together with silk and provide a better habitat.

Larvae of E. kuehniella showed limited mobility, only a few individuals of either first or third instars reaching soft wheat flours from a distance of $2 \mathrm{~m}$. Ephestia kuehniella typically lays eggs close to or on the surface of flours (Ozer, 1953; Kamel and Hassanein, 1965). Third instar larvae, compared to first instar ones, are more prepared to search for food over short distances $(1 \mathrm{~m})$. Likewise third instar larvae of $P$. interpunctella showed greater mobility compared to first instar ones (Locatelli and Limonta, 2004). This moth, unlike E. kuehniella, is able to cover long distances in order to find food: it was observed that $35 \%$ of third instar larvae were attracted by an artificial diet from a distance of $5 \mathrm{~m}$.

\section{Acknowledgments}

The authors are grateful to Doctor Emanuela Valtorta, Molino MV Erba (Como, Italy), for providing the different soft wheat flours.

\section{References}

Candura, G.S., 1928. A contribution to the knowledge of the moth infesting foodstuff, (Ephestia kuehniella Zeller) and of its parasite, Nemeritis canescens Gravenhorst. (Contributo alla conoscenza della tignola grigia delle provviste alimentari (Ephestia kuehniella Zeller) e del suo parassita Nemeritis canescens Gravenhorst.) Bollettino del Laboratorio di Zoologia generale e agraria del R. Istituto Superiore agrario di Portici 21, pp. 149-212.

Dobie, P., 1974. The laboratory assessment of the inherent susceptibility of maize varieties to post-harvest infestation by Sitophilus zeamais Motsch. (Coleoptera: Curculionidae). Journal of Stored Products Research 10, 183-197.

Fraenkel, G., Blewett, M., 1943a. The natural foods and food requirements of several species of stored products insects. Transaction of the Royal Entomological Society, London 93, 457-490.

Fraenkel, G., Blewett, M., 1943b. The basic food requirements of several insects Journal of Experimental Biology 20, 28-34.

Fraenkel, G., Blewett, M., 1943c. Vitamins of the B group required by insects. Nature (London) 151, 703-704.

Fraenkel, G., Blewett, M., 1946. Linoleic acid, vitamin E and other fat soluble substances in the nutrition of certain insects, Ephestia kuehniella, E. elutella E. cautella and Plodia interpunctella (Lep.). Journal of Experimental Biology 22, $172-190$.

Howe, R.W., 1971. A parameter for expressing the suitability of an environment for insect development. Journal of Stored Products Research 7, 63-65.

Jacob, T.A., Cox, P.D., 1977. The influence of temperature and humidity on the lifecycle of Ephestia kuehniella Zeller (Lepidoptera: Pyralidae). Journal of Stored Products Research 13, 107-118.

Kamel, A.H., Hassanein, M.A., 1965. Biological studies on the Mediterranean flour moth, Anagasta kuehniella Zeller. Bulletin de la Societe Entomologique de Égypte 49, 327-358.

Kunike, G., 1938. Die Feststellung des Nährwertes verschiedener Stoffe durch Frassversuche mit Vorratsschädlingen. Anzeiger fur Schadlingskunde 14, 101-105.

Lecato, G.L., 1976. Yield, development and weight of Cadra cautella (Walker) and Plodia interpunctella (Hübner) on twenty-one diets derived from natural products. Journal of Stored Products Research 12, 43-47.

Locatelli, D.P., Limonta, L., 2004. Ability of Plodia interpunctella (Hbn.) (Lepidoptera: Pyralidae) larvae to find food and flavours. Bollettino di Zoologia Agraria e Bachicoltura Serie II 36, 149-156.

MAFF (Ministry of Agriculture, Fisheries and Food, Agricultural Science Service), 1983. Control of storage pests using modified atmosphere. Research and Development Report. Storage Pests 1983, Book 251 (83), London, Her Majesty's Stationery Office.

Mbata, G.N., 1989. Studies on some aspects of the biology of Corcyra cephalonica (Stainton) (Lepidoptera: Galleriidae). Journal of Stored Products Research 25, 181-186.

Morère, J.L., 1971. Le carotène: substance indispensable pour la nutrition de Plodia interpunctella (Lep., Pyralidae). Compte Rendu Hebdomadaire des Séances de l'Academie de Sciences, Paris 272, pp. 2229-2231.

Nawrot, J., Warchalewski, J.R., Stasinska, B., Nowakowska, K., 1985. The effect of grain albumins, globulins and gliadins on larval development and longevity and fecundity of some stored product pests. Entomologia Experimentalis et Applicata 37, 187-192.

Osman, N., 1986. Development of the rice moth, Corcyra cephalonica (St.) on different grains. Pertanika 9, 155-159.

Ozer, M., 1953. Contribution a l'étude biologique de la teigne des farines. Annales des Épiphyties 4, 479-507.

Rathore, Y.S., Sachan, G.C., Bhattacharya, A.K., 1980. Growth and development of three-stored grain insect on Triticale. Science and Culture 46, 59-61.

Sharma, G.K., Jain, K.L., Pareek, B.L., 1978. Host preference and host-biology relations of Corcyra cephalonica and Ephestia cautella. Entomon 3, 37-40.

Stein, C.P., Parra, J.R.P., 1987. Biological aspects of Anagasta kuehniella (Zeller, 1879) on 2 food substrates. (Aspectos biológicos de Anagasta kuehniella (Zeller, 1879) criada em 2 substratos alimentares.). Anales de Sociedad Entomologica do Brasil 16, 173-185.

Süss, L., Locatelli, D.P., Cigognetti, I., 1988. Evaluation of the use of $\mathrm{CO}_{2}$ modified atmospheres in the disinfestation of cereals. (Valutazione dell'uso di atmosfere modificate con $\mathrm{CO}_{2}$ nella disinfestazione dei cereali.) In: Süss, L., Trematerra P. (Eds), Atti del Convegno "La Conservazione dei Cereali: Realtà ed Esperienze a Confronto" 1988, Bologna, pp. 199-209.

Trematerra, P., Locatelli, D.P., Pagani, M.A., 1984. Influence of the temperatures on the life cycle of Ephestia kuehniella (Zell.) on different flours and grits. (Influenza della temperatura sullo sviluppo di Ephestia kuehniella (Zell.) (Lepidoptera, Phycitidae) su diverse farine e semole.) In: Domenichini, G. (Ed.), Atti III Simposio sulla Difesa Antiparassitaria nelle Industrie Alimentari e la Protezione degli Alimenti, 1982, Piacenza, pp. 117-126. 